\title{
Diamonds, Foreign Aid, and the Uncertain Prospects for Post-Conflict Reconstruction in Sierra Leone
}

\author{
J. Andrew Grant*
}

\author{
August 2005
}

\begin{abstract}
This article examines the external and internal dimensions of post-conflict reconstruction in Sierra Leone. The United Nations, bilateral donors such as the United Kingdom, and transnational non-governmental organizations and aid agencies have been instrumental in providing much-needed external assistance to Sierra Leone during the latter stages of its civil war and in the immediate post-war period. Although foreign aid is a welcome source of external support for reconstruction efforts, it is finite like any other resource. Reconstruction must also address intangible issues such as corruption as well as the healing of society through the Truth and Reconciliation Commission and the Special Court for Sierra Leone. Diamond exports hold potential as an internal source to spur economic growth and reconstruction. However, as the article illustrates, many obstacles remain, ranging from governance weaknesses in terms of capacity and domestic regulatory schemes on diamonds to the existence of illicit mining and smuggling of diamonds to regional instability.
\end{abstract}

Keywords: Sierra Leone, natural resources, foreign aid, post-conflict reconstruction, development, governance

JEL classification: F35, O55, Q23

Copyright @ C UNU-WIDER 2005

* Center International and Comparative Studies, Northwestern University, Evanston, USA; email: j.andrew.grant@gmail.com

This is a revised version of the paper originally prepared for the WIDER conference on Making Peace Work, 4-5 June 2004.

UNU-WIDER acknowledges the financial contributions to its research programme by the governments of Denmark (Royal Ministry of Foreign Affairs), Finland (Ministry for Foreign Affairs), Norway (Royal Ministry of Foreign Affairs), Sweden (Swedish International Development Cooperation Agency—Sida) and the United Kingdom (Department for International Development). 


\section{Acknowledgements}

I thank Timothy Shaw, David Black, and Sandra MacLean for their helpful comments and suggestions on an earlier version of this article. The Social Sciences and Humanities Research Council of Canada funded this research. Joe Alie, Joseph Bangura, Olayinka Creighton-Randall, and John Harker provided invaluable logistical support that helped make the field research possible. The views presented are the author's own and do not represent those of the above institutions or individuals.

The World Institute for Development Economics Research (WIDER) was established by the United Nations University (UNU) as its first research and training centre and started work in Helsinki, Finland in 1985. The Institute undertakes applied research and policy analysis on structural changes affecting the developing and transitional economies, provides a forum for the advocacy of policies leading to robust, equitable and environmentally sustainable growth, and promotes capacity strengthening and training in the field of economic and social policy making. Work is carried out by staff researchers and visiting scholars in Helsinki and through networks of collaborating scholars and institutions around the world.

www.wider.unu.edu

publications@wider.unu.edu

UNU World Institute for Development Economics Research (UNU-WIDER)

Katajanokanlaituri 6 B, 00160 Helsinki, Finland

Camera-ready typescript prepared by Liisa Roponen at UNU-WIDER

The views expressed in this publication are those of the author(s). Publication does not imply endorsement by the Institute or the United Nations University, nor by the programme/project sponsors, of any of the views expressed. 


\section{Introduction}

The above quote is an optimistic maxim that translates from Krio, the lingua franca of Sierra Leone, as 'hope for the future'. More than three-and-a-half years after the official end to Sierra Leone's civil war, the country faces the daunting task of reconstruction amid much hope but decreasing optimism. Owing to more than a decade of civil conflict, much in the way of infrastructure has been destroyed, such as roads, bridges, hospitals, schools, electricity grids, communication links, housing, and commercial enterprises. Notably, what little existed in terms of infrastructure prior to the outbreak of civil war was already in poor shape due to more than two decades of corruption and 'bad' governance under Presidents Siaka Stevens (1968 to 1985) and Joseph Saidu Momoh (1985 to 1992). The social damage inflicted by the civil war should not be underestimated. Though difficult to assess in monetary terms, the losses incurred by Sierra Leoneans as a result of death, torture, injury, and displacement are substantial. Thus, the scope and depth of post-conflict reconstruction must extend beyond the simple rebuilding of physical infrastructure. Intangible social needs must be met, ranging from healing societal scars from the civil war to eradicating corruption in the public and corporate arenas.

Post-conflict reconstruction is an imposing undertaking in any country, and it must be able to draw upon external and internal sources of support. The United Nations (UN), bilateral donors such as the United Kingdom, and transnational non-governmental organizations (NGOs) and aid agencies have been instrumental in providing external assistance to Sierra Leone during the latter stages of the civil war and in the immediate post-war period. Internally, the combination of local NGO efforts, a feisty media, and a small yet vibrant business sector has driven political and economic aspects of reconstruction. Diamond exports are growing at an impressive annual rate. However, the governing Sierra Leone People's Party (SLPP) still lacks effective capacity to implement various policies and legislation. Corruption in government and the corporate sectors remains, though reduced and better concealed in comparison to the past.

The purpose of this article is to illustrate the above dimensions of post-conflict reconstruction in Sierra Leone. External and internal resources will be examined in order to assess the prospects for reconstruction efforts. Foreign aid represents the bulk of the external sources of support, though its imminent reduction is a significant concern. Donors have a history of drastically reducing assistance once stability returns to a country, which tends to coincide with the four-year anniversary of the official end of hostilities (DFID 2005: 13). Internal resources, such as diamond exports, offer much potential as a means to spur economic growth and reconstruction. While diamonds are being counted on for aiding reconstruction, this valuable natural resource may also very well disrupt reconstruction efforts. The chances for disruption are great as many governance obstacles remain, ranging from weaknesses in the international and domestic regulatory schemes on diamonds to illicit mining and smuggling of diamonds from mines located primarily in the Eastern part of Sierra Leone to regional instability in the Mano River basin. In short, lack of government capacity and the persistence of corruption are significant obstacles to successful reconstruction. It is uncertain-at least in the short term-whether these twin impediments will be overcome. 


\section{Post-conflict reconstruction}

The move from conflict to reconstruction is complex and subject to delays, reversals, and myriad unforeseen events. Addison (2003) identifies two key objectives for such a task. First, and logically, veritable peace must be present throughout the country. Second, the goal of 'broad-based recovery that improves the incomes and human development indicators of the majority of people, especially the poor' (Addison 2003: 3, original emphasis) must exist. If the individual is the primary focus of security-human security, 1 more specifically - then conditions associated with economic wellbeing, adequate food, health, and environmental provisions, political freedoms, and the absence of wide-scale physical threat are relevant. Of interest, then, are factors ranging from quantitative indicators such as disarmament, demobilization and reintegration (DDR) figures, per capita income rates, human development index scores, and foreign aid inflows to qualitative measures such as perception of corruption, state-society relations, and the health of the 'social fabric' of post-war Sierra Leone.

Most importantly, peace currently exists in Sierra Leone. January 2002 witnessed the completion of the disarmament process as well as the formal declaration that the civil war indeed was over. After nearly five years of operations, Sierra Leone's National Committee for Disarmament, Demobilization and Reintegration (NCDDR) came to an official close on 31 March 2004. A total of 72,490 combatants were disarmed as part of the NCDDR programme, and 71,043 were demobilized (UNOCHA 2004a). The reintegration phase consisted of a choice of vocational training, formal schooling, or receiving tools for various trades as well as farming. 63,545 former combatants participated in the reintegration segment, including 6,845 former child soldiers. Although these figures are impressive, approximately 9,000 former combatants did not complete the entire programme. In other words, about one in eight ex-combatants (12.5 per cent) did not make it to the reintegration phase. The Executive Secretary of the NCDDR, Francis Kaikai, posited several reasons for the discrepancy, ranging from 'self-integration' to avoiding the stigma of belonging to the rebel group, the Revolutionary United Front (RUF). Most former members of the pro-Kabbah Civil Defence Forces (CDF) 'were not interested in reintegration because they only fought to defend their villages' (quoted in UNOCHA 2004a).

Given its relative success, Sierra Leone's NCDDR has drawn great interest from other African countries embarking on their own DDR programmes. An official with the World Bank characterized the US\$36.5 million project as 'the best practice example throughout the world of a successful disarmament demobilization reintegration programme'.2 In contrast, Alan Doss, head of the United Nations Development Programme (UNDP) office in Sierra Leone, correctly observed that the former combatants 'have joined another, a larger army of young people who are seeking gainful employment ... [they] must now compete with all other citizens for any assistance or support provided by the government' (quoted in UNOCHA 2004a). According to a report prepared by the International Crisis Group (ICG 2003: 1), a 'large number of excombatants [are] unhappy with the reintegration program and [are] facing bleak employment prospects in the formal economy'. For instance, part of the reason for the

1 Human security is a multi-faceted, albeit contested, term. See for example Burgess and Owen (2004) and Paris (2002).

2 Murray, quoted in UNOCHA (2004a). 
very low wages paid to artisanal diamond miners is the influx of people from all part of the country to the diamond fields of Kono and Tongo. Thus, the sombre assessments offered by Doss and the ICG are prescient, as one wonders what type or level of support the incumbent SLPP government will provide given its lack of capacity and resources.

In addition to former combatants, the civilian population must experience an improvement in living conditions and employment prospects. Over the past decade, Sierra Leone has been consistently ranked near or at the very bottom of the human development index (HDI) rankings, which is no surprise given the fact that the country was embroiled in protracted civil conflict. In 2004, the UNDP report ranked Sierra Leone $177^{\text {th }}$ out of 177 countries studied, with a HDI value of 0.273 (UNDP 2004: 142). In contrast, Sub-Saharan Africa received a score of 0.465. It is important to note that the 2004 HDI values are based on 2002 figures. Therefore, technically, the civil war had just come to an official end, and it is not unreasonable to assume some improvement in this dismal ranking.

Figure 1 includes several civil war years as well as the subsequent reconstruction phase in Sierra Leone. The ebb and flow of the civil war is reflected in the above statistics. Sierra Leone is also a Heavily Indebted Poor Country (HIPC). Its budget is highly dependent upon external donor support. For instance, approximately 65 per cent of Sierra Leone's government budget comes from the United Kingdom through the British Department for International Development (DFID) (Davies 2003: 5). While the meagre size of the government budget represents a serious impediment, political will to address

Figure 1

Sierra Leone, per capita income, selected years

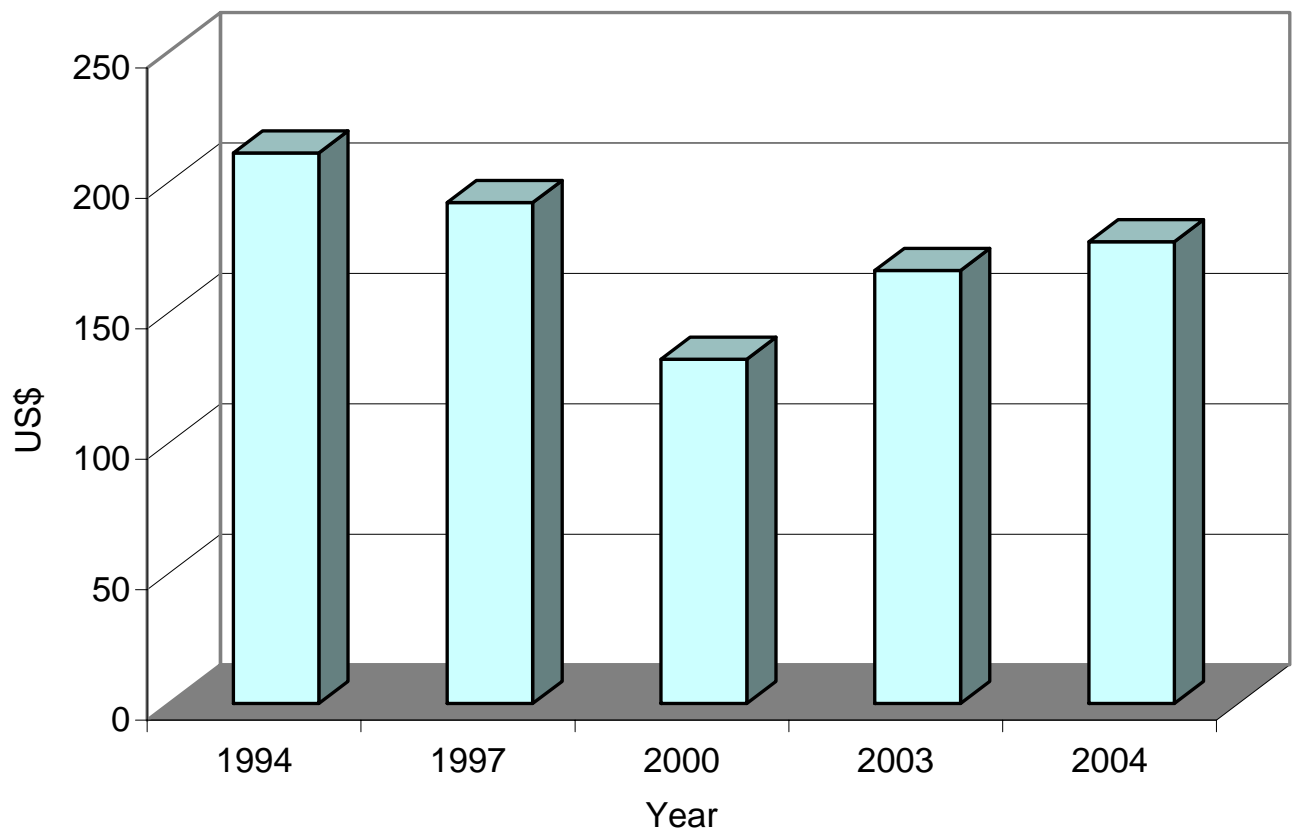

Source: Simpson (2003: 27). 
the condition of the country's poor must be amplified. All governments are faced with difficult choices in terms of expenditures of scarce resources.

Employment prospects are slim, especially for those lacking technical or knowledgebased skills. Even those in various professions, such as school and college teachers, often experience delays in receiving regular payment of wages. Casual employment opportunities may be found, though frequency varies considerably. For instance, adult casual labourers make about 80,000 Le per month (based on a 20-day, eight-hour-perday, five-day work week) in Freetown. ${ }^{3}$ No additional benefits such as health care, employment insurance, or pension, are received (or deducted).

Amid the widespread poverty, which is particularly evident in Freetown, many new houses, shops, and small office buildings are either being built or renovated. While some of this economic activity may be attributed to a 'spin-off' effect from the presence of the UN and its various agencies, donor countries such as the UK and the USA, transnational NGOs, and aid organizations, wealth is being generated by other means. Likely suspects are illicit diamond exports and other forms of corruption in government.

\section{Foreign aid}

Foreign aid, if designed and implemented properly, provides an invaluable source of human security. As Addison (1998: 4) avers:

while aid provides essential help, success ultimately depends upon the capacities and actions of national actors. These are: communities, entrepreneurs, and the state. But communities are impoverished, private sectors are underdeveloped, and states are weak. Success therefore requires overcoming each of these problems.

Sierra Leone has a reputation for donor dependence. According to the World Food Programme (WFP), aid accounts for approximately 60 per cent of Sierra Leone's gross national product (GNP). 4 Yet, during the first decade of independence, the country received only a modest amount of foreign aid.

Including the final year of British colonial rule (1960), Sierra Leone received a total of US\$125.3 million from 1960 to 1969.5 Figure 2 displays the annual amounts of foreign aid received by Sierra Leone from 1960 to 2002. Interestingly, Sierra Leone produced an outflow of US\$2.3 million in various forms of assistance funds in 1970. As Stevens consolidated his power base, foreign aid receipts began to grow. Under the kleptocratic and often incompetent regimes of Stevens and Momoh, substantial foreign aid inflows became a regular occurrence in the 1970s and 1980s. By 1991, hundreds of millions of dollars in foreign aid was entering the country each year. From 1971 to 2002, Sierra Leone received a total of US\$3.48 billion in various forms of foreign aid.

3 Author's interview with a member of the Campaign for Good Governance (CGG), Freetown, Sierra Leone, 10 June 2003.

4 World Food Programme (2005).

5 Data derived from OECD (various years). This sum comprises total amounts of official development assistance (ODA), other bilateral transactions know as other official flows (OOFs), and private sector flows (PSFs), which include guaranteed export credits and private bank loans. 
Much of the foreign aid funds benefited Sierra Leone's ruling elites indirectly through dubious development schemes or patronage rents. During the cold war, donors would often turn a blind eye to government corruption or mismanagement of aid funds. Although bad governance by recipients of aid funds has not been eradicated, donors have attempted to cut down on these practices by linking funds to democratic elections and good governance in recipient states. The relationship remains problematic, as withheld foreign aid hurts those most in need.

Recent inflows of various forms of foreign aid have been instrumental in bolstering the human security of Sierra Leoneans. For instance, Sierra Leone received about 89,000 metric tons of food aid in 2002.6 In addition to foreign aid, Sierra Leone has benefited from direct and indirect spending by the international community. As one report put it: 'The international community has invested billions of US dollars to end the civil war and move the country toward peace' (ICG 2003: i). The UN has spent hundreds of millions of dollars as part of its operations in Sierra Leone. For example, from 1 July 2003 to 30 June 2004, the United Nations Mission in Sierra Leone (UNAMSIL) budget was US\$543.49 million. UNAMSIL's approved budget for 1 July 2004 to 30 June 2005 is US\$291.6 million. 7

Although foreign aid is a welcome source of external support for reconstruction efforts, it is finite like any other resource. Donor fatigue with respect to Sierra Leone may very well set in-perhaps a question of 'when' rather than 'if'.

Figure 2

Total aid to Sierra Leone, 1960-2002

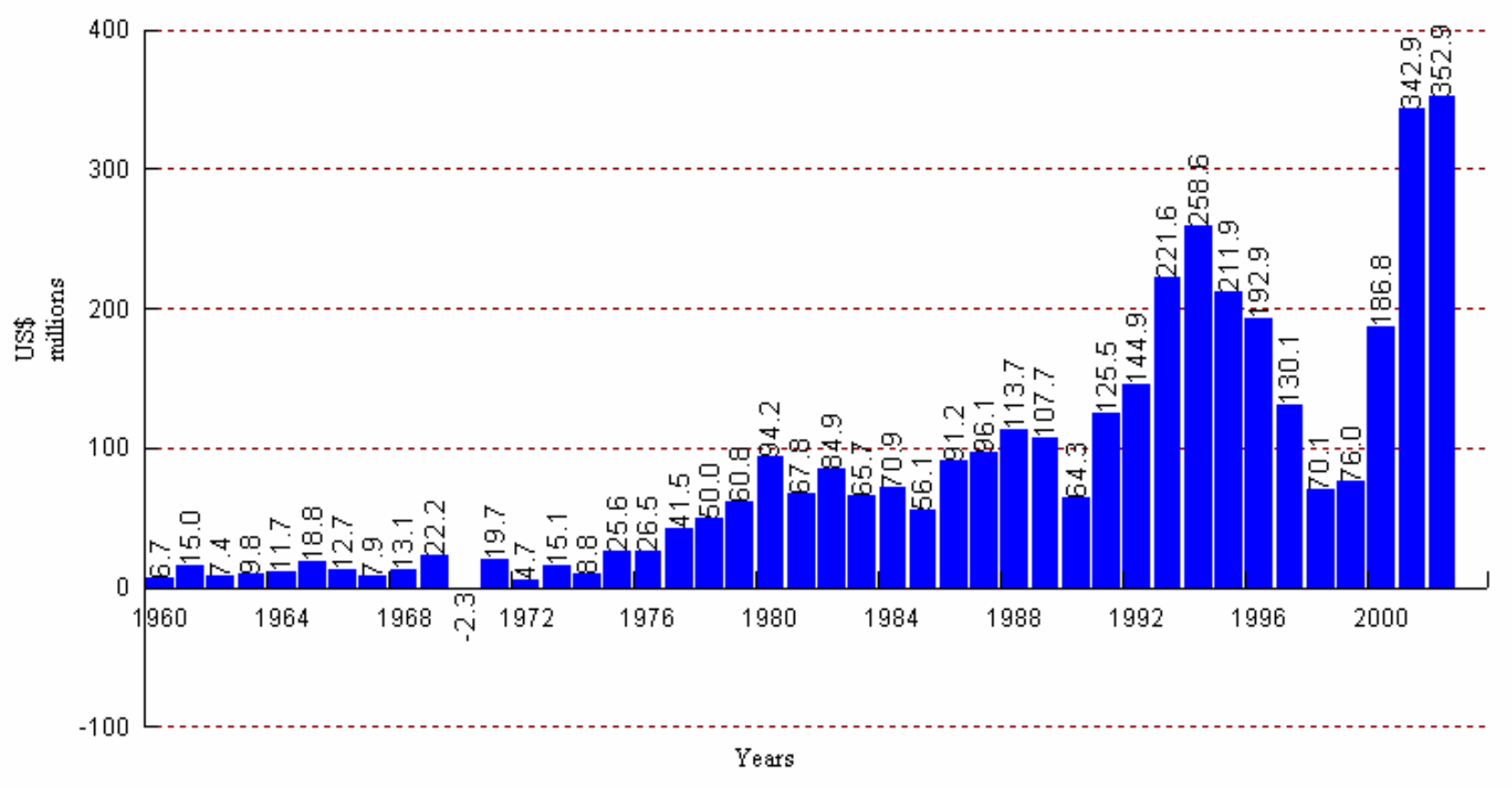

Source: OECD (various years).

6 World Food Programme (2005).

7 United Nations (2005). 


\section{State and society}

The state is often in a position of weakness following the cessation of hostilities. Indeed, as Bornstein and Munro (2003: 221) assert, 'A central difficulty of war-torn societies is that the state is both an agent and an object of reconstruction'. It follows that during post-conflict reconstruction, one of the main goals is to strengthen the political authority of the state. In other words, there is a concerted effort to boost state sovereignty. This is particularly important after a civil war, wherein the legitimacy of the incumbent government may be either questionable or fragile. Democratic elections are now considered an essential first step in this regard (although elections can also cause new tensions). Thus, it is unsurprising that elections are often held shortly after the formal end of hostilities in order to confer a measure of legitimacy to the governing regime. This was the case in Sierra Leone, as presidential and parliamentary elections were held four months after the conclusion of the civil war.

Although President Ahmed Tejan Kabbah was re-elected and the governing SLPP retained its parliamentary majority — both by comfortable margins - in May 2002, the electorate has become increasingly unhappy with the lack of improvement in the economy and a host of other issues pertaining to reconstruction. Local NGOs, such as the Campaign for Good Governance (CGG) and the Network Movement for Justice and Development (NMJD), have a reputation for pressing the government for positive change. The government is also subject to a vocal and often critical private press, dominated by approximately 50 newspapers that are published either daily or weekly and exhibit varying degrees of editorial and reporting quality (Reno 2004: 14-6). News stories of government corruption or complaints pertaining to lack of government capacity to provide various public services tend to dominate the front and rear pages of these thin periodicals. Government corruption and weak capacity were problems well before the civil war began; thus, the simple act of holding free and fair elections should not be expected to solve these problems.

If reconstruction plans are to be effective, then international aid agencies must focus on addressing one of the leading causes of Sierra Leone's civil war: corruption. Not only are foreign donors wary of corruption, but so too-and perhaps most importantly for long-term reconstruction and sustainable economic growth-are foreign investors. Of course, eradicating corruption is easier said than done. This applies to the diamond industry as well, though difficult to prove. Nevertheless, some relatively inexpensive though useful changes could be implemented, such as drastically improving transparency in government accounts and its awarding of contracts and giving the AntiCorruption Commission (ACC) greater autonomy by moving to an 'arms' length' position vis-à-vis the office of the president. Granting the ACC greater powers to prosecute suspected offenders will also help address corruption. However, given the problems within Sierra Leone's judicial system, ranging from lack of funding to reports of bribery, 8 strengthening the ACC may accomplish little over the short term.

Improving government capacity is no easy feat. But, reducing government corruption will have a positive effect on its ability to implement policy, enforce laws and regulations, and ensure that scarce funds reach those segments of the population in greatest need. Sierra Leone's score is still low in terms of 'anti-corruption and

8 See for example ICG (2003 and 2004). 
transparency' at 3.01 out of a possible 7 points (Reno 2004: 1). If the perception grows that corruption has decreased in Sierra Leone, then international and bilateral aid and lending agencies will have greater confidence in allocating assistance to the country. This will be key in terms of securing funds for medium- and long-term reconstruction and development.

While it is easier to measure the impact of large-scale reconstruction projects that rebuild physical infrastructure, reconstruction of the social fabric of Sierra Leonean society is equally important. Public goods such as 'justice' are subjective and open to varying interpretations, and therefore escape easy quantification. Though, if any lesson is to be learned from Sierra Leone's civil war and the preceding decades of poor governance, it is that sources of political, economic, and social grievances cannot be ignored. Sierra Leone established a Truth and Reconciliation Commission (TRC) and hosts its own Special Court, a hybrid-type of tribunal that is administered in conjunction with the UN. The United Kingdom's DFID and the International Military Advisory and Training Team (IMATT) each have instituted several programmes aimed at ameliorating civil-military relations throughout Sierra Leone. While the UN and three G-8 members - the UK, the US, and Canada-have provided personnel, training, material, as well as logistical and financial support to Sierra Leone, the aforementioned initiatives are in jeopardy due to a lack of funding. Despite the high expectations the TRC, which held hearings from April to August 2003, it was forced to operate on a shoestring budget. The TRC received US $\$ 2.3$ million in funding-just over half of its projected budget (Reno 2004: 8). Aside from the opening ceremonies, most sessions of the TRC were poorly attended (particularly the sessions that were held in Freetown) both by those expected to testify and by the general public. Much more local and international media attention was allocated to the Special Court for Sierra Leone (SCSL), which had already issued a number of indictments and was perceived as having more clout in terms of adjudicating war crimes.

Amid concerns regarding future funding needs and projected operating costs, the new edifice constructed to house the SCSL was officially inaugurated on 10 March 2004 under tight security. The SCSL-whose construction cost of US\$3.4 million was paid for by the USA along with several other foreign countries-now enjoys permanent chambers in which to prosecute the indictments it issued to individuals accused of war crimes committed during the civil war. In June 2004, the SCSL heard its first set of cases. Eight counts - consisting of various violations of international law including war crimes and crimes against humanity-have been levied against former CDF leaders Sam Hinga Norman, Allieu Kondewa, and Moinina Fofana. The case against Norman, a former Minister of Internal Affairs in Kabbah's government, has drawn the most criticism, 9 as many see him as being instrumental in garnering much needed military assistance to pro-government forces by leading the Kamajors and the CDF. Although the CDF's tactics were at times nearly as brutal as the RUF's, the former did provide much-needed support for UN forces and British troops during the final years of the conflict. Many commentators, ranging from outside observers to Sierra Leoneans themselves, have questioned the validity of Norman's indictment. Op-ed pieces calling for Norman's release are common in Sierra Leone's daily and weekly newspapers.

9 See for example Penhold in Gberie (2005b, p. 122). 
During the inauguration of the SCSL, a group of demonstrators clad in 'Free Hinga Norman’ t-shirts protested against Hinga’s indictment and demanded his release.10

Some commentators fear that this joint trial of former CDF leaders presents the gravest threat to Sierra Leone's internal security. The Kamajors - the largest contingent within the CDF-are generally unhappy that Hinga, Kondewa, and Fofana are facing charges before the SCSL. The Kamajors have retained some semblance of organizational readiness despite assurances that they were disbanded in 2002. In contrast, after conducting numerous interviews with former CDF combatants and UNAMSIL officials, an ICG report concluded that a lack of manpower and weaponry means that although 'the Kamajors could cause local disruptions, there is little evidence they could destabilize the country' (ICG 2003: 14). In any case, the security situation within Sierra Leone will change once UNAMSIL's 3,230 peacekeeping troops depart by 31 December 2005.

A trio of former RUF leaders are also on trial at the SCSL. The RUF has been disarmed, demobilized, and metamorphosed into a formal-albeit unsuccessful-political party. Yet, like the CDF, former RUF combatants have not completely 'disappeared'. Some former RUF combatants have crossed into Liberia. While Liberia's civil war came to a close in August 2003, the UN has yet to make its presence felt in much of the outlying areas of the country. There is very little in the way of government presence (military or police) in Lofa County of Liberia and the 'Parrot's Beak' region of Guinea and surrounding border areas. Thus, the border region between Sierra Leone, Liberia, and Guinea provides an ideal, remote area in which to hide or attempt to blend back into local communities. Although there are rumours that small caches of weapons exist in parts of Sierra Leone and that groups of RUF combatants could resurrect themselves on relatively short notice, 11 the group is a shell of its former self and poses no veritable threat to the current peace.

\section{Internal resources: from agriculture to diamonds}

Reconstruction efforts must also be sustained from internal resources, such as tax revenues from the export of rough diamonds and other commodities to various indirect revenues from overall trade of goods and services. Agriculture is important not only for feeding the domestic population, but also for export earnings. Prior to the start of the civil war, Sierra Leone's agricultural sector accounted for just over half of the country's GDP.12 Food security is an important component of human security. The reintroduction of livestock to rural areas following the civil war is a small yet important step in rebuilding the food-producing capacity of the country. While chickens remain ubiquitous, the sighting of the occasional cow along the route from Mile 91 to Kenema, for example, was perceived by one aid worker to be a very important indicator that an

10 According to one report, police arrested five of the demonstrators for failing to register their protest; however, the demonstrators were later released and the charges were apparently dismissed (UNOCHA, 2004b).

11 Author's personal communication with an aid worker, Koidu, Kono District, Sierra Leone, 10 May 2003.

12 World Food Programme (2005). 
initial step towards agricultural recovery in the rural parts of the country had begun.13 A similar example of animal husbandry is that pigs are steadily being reintroduced to smallholder farms. However, agricultural production in Sierra Leone suffers from low export prices, infrastructural impediments such as poor roads, and slow (and corrupt) seaports. Sierra Leone, once self-sufficient in foodstuffs and an exporter of its main dietary staple-rice-imports food and receives food aid. It is not uncommon to come across food items clearly labelled as international food aid-donated through agencies such as the WFP or bilateral donor countries-for sale in small market stalls throughout the country. This practice is not confined to Sierra Leone, for the 're-sale' or trade of donated foodstuffs is but one facet of the political economy of international food aid.

As the country progresses along the path to reconstruction and domestic food production increases, it is expected that food aid needs will diminish. Yet, this expectation should not be taken as fact. Sierra Leone's agricultural production also suffers from a shortage of manpower. The lure of 'striking it rich' in the diamond mines draws a large number of potential workers away from the agricultural sector. This is a definite limitation of relying on diamonds as a primary means of reconstruction. Flooding the labour market in the diamond sector will further reduce the already paltry wages paid to miners. By definition, subsistence farming will not witness a proportionate rise in wages due to fewer farmers. Rather, agricultural production is expected to fall.

In a similar vein, Sierra Leone has sizeable deposits of rutile, bauxite, gold, iron ore, and other minerals, though the focus of export-led reconstruction inevitably centres on diamonds. On the one hand, this is not surprising given the importance of diamond exports to the Sierra Leonean economy since the colonial era. Yet, on the other hand, diamonds have proven to be a problematic source of export earnings owing to challenges ranging from smuggling and illicit mining to government corruption. Furthermore, diamonds served to sustain the rebel group, RUF, whose particularly vicious methods of striking fear in the hearts of civilian populations (e.g., amputation of various body parts and rape) eventually brought attention to not only the civil war but also the trade of 'conflict' or 'blood' diamonds. These notorious qualities notwithstanding, diamonds persist as a panacea of sorts for many outside observers and Sierra Leoneans alike—a means to solve all of Sierra Leone's economic ills.

\subsection{Sierra Leone's diamonds 14}

Diamonds played an important role in Sierra Leone’s civil war (Reno 1995, 1998: 113-45; Abiodun 1999; Zack-Williams 1999; Smillie, Gberie and Hazleton 2000; Hirsch 2001; Grant 2005). And, depending on whom you talk to, diamonds are either a blessing or a curse for Sierra Leone. Regardless, diamond revenues represent an important component of Sierra Leone's economy. In terms of employment, diamond mining is the leading employer of unskilled labour. Diamond mining is also an important supporter of dependent industries. Income earned by miners attracts smallscale traders of foodstuffs and other small consumer items to the mining areas and

13 Author's personal communication with an aid worker, Kenema, Kenema District, Sierra Leone, 8 May 2003.

14 Parts of this section draw upon the author's contribution to Gberie (2004). 
nearby villages and towns. During the first part of the 1990s, diamonds comprised about 20 per cent of total export earnings. Owing to the disruption of rutile and ilmenite production in January 1995 because of the war-which had garnered about half of all export earnings - diamonds have become the primary income earner for the economy and, indeed, government coffers.

Those who believe that diamonds are a curse for Sierra Leone point to the corrupt handling of diamond revenues under the regimes of Stevens and Momoh, and to the civil war itself. The legacy of government corruption and conflict diamonds combined with the importance of diamonds to the country's economy makes Sierra Leone a prime

candidate for following the prescriptions of the Kimberley Process Certification Scheme (KPCS), 15 which is the main regulatory document of the Kimberley Process. Since its inception in 2000, the Kimberley Process has sought to end the trade of conflict diamonds through multilateral efforts aimed at imposing strict verification and trade controls on diamonds based on the collaboration of not only state actors, but also nonstate actors such as diamond firms and industry associations as well as NGOs (Grant and Taylor 2004). When referring to the KPCS, Sierra Leone's Minister of Mineral Resources, Alhaji M. S. Deen (2003: 4-5) stated: 'We expect that the impact of this process on the diamond trade, especially in Sierra Leone, will be spectacular'.

Figure 3 depicts the rapid increase in diamond exports through official, government of Sierra Leone, channels. The recorded output by value for 2004 more than tripled the country's output for 2002. Notably, Sierra Leonean diamonds tend to be of excellent quality, thereby fetching a high average price per carat.

Figure 3

Official diamond exports by value, Sierra Leone 1999-2004

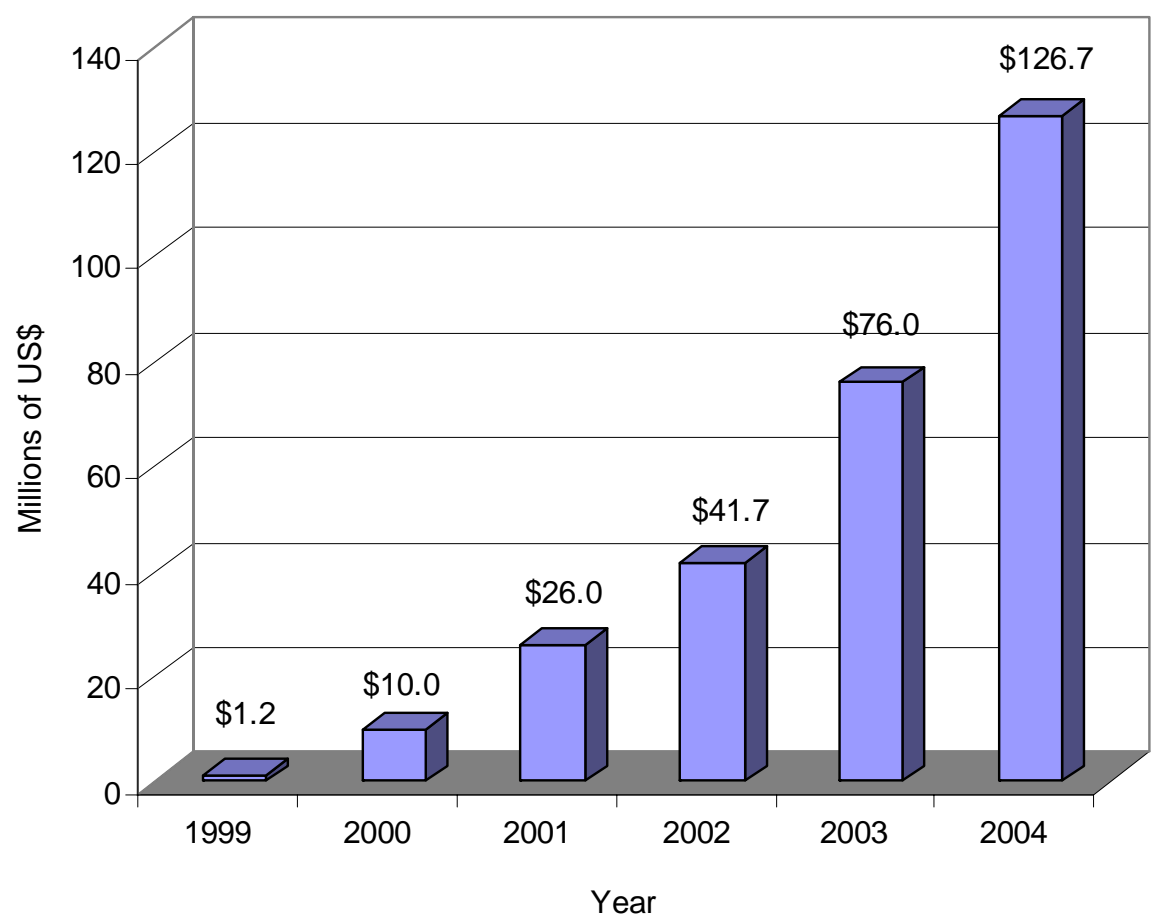

Source: Government of Sierra Leone Gold and Diamond Department (GDD).

15 Available at www.kimberleyprocess.com:8080/site/content/KPCS.pdf. Accessed 11 June 2005. 
While these numbers are impressive, some industry experts remain doubtful that all of Sierra Leone's diamonds are passing through licit conduits: 'the majority of gemstones mined are still smuggled out of the country. Independent estimates value Sierra Leone's annual production of diamonds at US US\$200 million to US US\$400 million' (UNOCHA 2003). Decades of corruption, mismanagement, and smuggling of the country's diamond resources-not to mention the threats to human security posed by conflict diamonds-present monumental challenges to effective and equitable governance of this all-important mineral. Given the aforementioned disparity between the value of legally exported diamonds and smuggled diamonds, it is important to assess the extent to which the Sierra Leonean government-through the use of its Certificate of Origin and national legislation under the 1994 Mines and Minerals Act-is effectively implementing the KPCS’s minimum standards.

In Sierra Leone, the designated export authority of diamond resources is the Gold and Diamond Department (GDD), which falls under the jurisdiction of the National Revenue Agency (NRA). The GDD coordinates very closely with the Ministry of Mineral Resources (MMR). Following valuation, the GDD is responsible for collecting the 3 per cent levy on all exported diamonds. While this figure may seem small to some, the portion to be directed to community development projects in the mining regions through the Diamond Area Community Development Fund (DACDF) is expected to reach as much as US\$950,250 for 2004. Also, there is a fear that a high tax rate will encourage diamond exporters to either evade or actively subvert official channels and encourage smuggling. This 3 per cent levy is then allocated accordingly: DACDF, 0.75 per cent; GDD, 0.75 per cent; 'special training', 0.75 per cent; external/independent valuator, 0.50 per cent; and Mines Monitoring Unit (MMU), 0.25 per cent.

Individuals convicted of contravening the laws of the Mines and Minerals Act are subject to fines and/or jail time as well as having their diamonds, mining implements, and related equipment confiscated. Non-citizens face expulsion from Sierra Leone after the fines are paid and/or jail time is served. In a September 2003 court decision, former Transport and Communications Minister, Momoh Pujeh, was sentenced to two years in jail for the illegal possession of diamonds (PANA Press 2003a).

Sierra Leone's so-called ' 40 per cent' law is an incentive to encourage individuals to report illicit diamond mining. The informant receives 40 per cent of the value of illicit diamonds that are seized by the authorities. This law (which also applies to illicitly mined gold) has demonstrated modest success since its recent inception. As of early 2003, a total of US\$100,000 in illicitly mined diamonds and gold had been seized as a result of the 40 per cent law (Kamara 2003: 12). While raids based on informant tips or other information sources tend to be successful in terms of seizing illicitly mined diamonds and arresting illicit miners and dealers, the raids are infrequent due primarily to a lack of financial resources. While mines wardens and monitors are responsible for the bulk of the internal controls of Sierra Leone's diamond industry, the Sierra Leone Police (SLP) often provides support in the field. In November 2003, four SLP officers embarked on a six-week course in South Africa to receive training in policing strategies and criminal investigation methods with respect to diamond mining (PANA Press 2003b).

Overall, Sierra Leone deserves a satisfactory grade on sincerity and desire, as Sierra Leone's national diamond certification scheme reflects much of the spirit of the Kimberley Process and meets several 'minimum standards' as set out in the KPCS. For 
instance, the GDD maintains an up-to-date (with a one- to two-month lag) set of diamond export statistics as well as a database containing the names, addresses, and license numbers (with date of granting) of all diamond exporters. Sierra Leone's export certificate along with the container, bag, and seal are what might be best described as forgery- and tamper-resistant (rather than forgery- and tamper-proof). Though not required by KPCS minimum standards, Sierra Leone's so-called ' 40 per cent' law has enjoyed some success as an incentive to encourage individuals to report illicit diamond mining.

While the above efforts are laudable, it should be emphasized that Sierra Leone's national certification scheme does not meet all KPCS minimum standards. Perhaps the most glaring deficiency is the lack of a veritable audit trail from diamond mine to market. According to KPCS minimum standards, a chain of custody that can be checked back from the GDD to dealers to diggers is supposed to be in operation. While a detailed database of digger, dealer, and exporter licensees could be established, there is no rule in place that requires the inclusion of the digger and/or dealer on Sierra Leone's Certificate of Origin for diamonds. Even if the name and license number of the digger and dealer were required on the Certificate of Origin, it is unclear how this information could be verified under the current structure of the certification regime in Sierra Leone. Moreover, the current Certificate of Origin does not specify the exact mine of provenance of the parcel of diamonds. In fact, many parcels of diamonds submitted for valuation and certification by diamond exporters at the GDD come from several different mines and kingdoms (administrative sub-districts).

An important aspect of KPCS minimum standards is the ability of a member country and its government agencies to enforce its national certification scheme. In Sierra Leone, mines wardens and monitoring officers not only lack in-depth police training, but also face logistical challenges to proper monitoring and enforcement of diamond mining and dealing regulations due to poor infrastructure (i.e., lack of proper transportation and communication technologies). 16 These challenges add to the already daunting task of policing a wide geographic area that is difficult to traverse. Rumours also abound that bribery of mines wardens, monitoring officers, and customs officials is not uncommon. The meagre wages of those responsible for enforcing many of the rules and regulations of the diamond certification scheme contribute to the likelihood of asking for 'tips' or even the acceptance of outright bribes (Ndola-Myers 2003: 80).

\section{Conclusion}

While foreign donors have been footing the bill for reconstruction projects such as the recently concluded NCDDR programme, it is uncertain what level of international aid will be received by Sierra Leone in the medium and long term. The source of this uncertainty rests on the fact that foreign aid is subject to myriad factors within donor and recipient states as well as in the international arena. Post-conflict reconstruction projects in Africa and other parts of the world will continue to draw upon a limited pool of foreign aid. Regionally, several West African countries are experiencing varying bouts of insecurity. Liberia is already drawing away foreign aid and other external

16 These concerns are also echoed in Gberie (2005a) as well as in the findings of a February 2005 Kimberley Process ‘Review Mission’ to Sierra Leone. See UNSC (2005, Para. 22). 
sources of assistance after its own period of civil war and venal governance under Charles Taylor. Côte d'Ivoire remains unstable, and the future of Guinea is clouded, as rumours of an impending coup persist. Guinean president Lansana Conté's health is poor, and his grip on an opaque regime may be slipping.

Internal sources of reconstruction are equally uncertain, though for different reasons. Diamond exports have been growing at a healthy rate since the final years of the civil war, particularly since the official end of hostilities at the beginning of 2002. While this appears promising, several obstacles remain. First, diamond smuggling and illicit mining persist in Sierra Leone, despite the strengthening of legislation. The combination of weak state capacity and the logistical barriers to adequately policing artisanal diamond mining is daunting. Second, regional instability may place the diamond mines at risk once again should hostilities resume in Liberia or emerge in Guinea. Furthermore, it is risky to rely on a single commodity for the bulk of export earnings. Rough diamond prices have stayed remarkably stable, and demand is strong. For instance, the chances of a consumer boycott of diamonds are slim. However, diamond resources themselves are finite. Although estimates of Sierra Leone's diamonds reserves are often quite large, they are just that-estimates. Some offshore oil exists, but the contractual process surrounding the bidding for drilling blocks has taken longer than originally envisioned. Sierra Leone's fisheries are subject to poaching by foreign trawlers, as enforcement of fishing rights and boundaries is virtually non-existent. The impending return of rutile and bauxite extraction will help, but the problem of relying on finite, non-renewable resources remains.

The present challenge is to focus on more medium- and long-term reconstruction solutions. While this may entail more conventional forms of development, lessons from the past must be heeded in order to reduce the potential for waste and corruption. As Addison (1998: 30) reminds us: 'Public money must be focused on core services of most benefit to the poor. These include primary education, basic health services and safe water and sanitation'. However, this will likely prove difficult to implement, as neo-liberal strategies tend to concentrate on reducing government expenditures and taxation. This favours the wealthier segments of society, not the poor.

If 'hope for the future' is to be realized, the psychological and physical trauma endured by the people of Sierra Leone cannot be ignored by efforts to spur economic growth and reconstruction. This is crucial to prevent a resumption of the vicious cycle of greed and grievance that led to the outbreak of civil war in the first place. The overarching goal of reconstruction should be broad-based, sustainable, and equitable in terms of economic and social development. Yet, the aforementioned evidence suggests that the prospects for Sierra Leone's post-conflict reconstruction remain uncertain at best.

\section{References}

Abiodun, A. (1999). 'Diamonds Are Forever...But so also Are the Controversies: Diamonds and the Actors in Sierra Leone’s Civil War'. Civil Wars, 2 (3): 43-64.

Addison, T. (1998). 'Underdevelopment, Transition and Reconstruction in Sub-Saharan Africa’. WIDER Research for Action No. 45. Helsinki: UNU-WIDER. 
Addison, T. (2003). 'Introduction', in T. Addison (ed.), From Conflict to Recovery in Africa. Oxford: Oxford University Press, 3-16.

Bornstein, L., and W. Munro (2003). 'Agency, Space, and Power: The Geometries of Post-Conflict Development in Africa', in M. S. Smith (ed.), Globalizing Africa. Trenton: Africa World Press, 217-46.

Burgess, P. J., and T. Owen (eds) (2004). 'What Is “Human Security”?'. Security Dialogue, 35 (3): 345-71.

Davies, D. (2003). 'Sierra Leone First in Southwark'. West Africa, 43-76 (19-25 May).

Deen, A. M. S. (2003). 'The Future and Security of Diamond Mining in Sierra Leone'. Sierra Leone: DFID Diamond Sector Workshop. Freetown: DFID, 1-7.

DFID (Department for International Development) (2005). Why We Need to Work More Effectively in Fragile States. London: DFID.

Gberie, L. (ed.) (2004). Diamond Industry Annual Review: Sierra Leone 2004. Ottawa: Partnership Africa Canada.

Gberie, L. (ed.) (2005a). Diamond Industry Annual Review: Sierra Leone 2005. Ottawa: Partnership Africa Canada.

Gberie, L. (2005b). 'An Interview with Peter Penhold'. African Affairs, 104 (414): 117-25.

Grant, J. A. (2005). 'Salone's Sorrow: The Ominous Legacy of Diamonds in Sierra Leone', in A. Mehler and M. Basedau (eds), Resource Politics in Sub-Saharan Africa. Hamburg: Institute of African Affairs, 259-81.

Grant, J. A., and I. Taylor (2004). 'Global Governance and Conflict Diamonds: The Kimberley Process and the Quest for Clean Gems'. The Round Table: The Commonwealth Journal of International Affairs, 93 (375): 385-401.

Hirsch, J. L. (2001). Sierra Leone: Diamonds and the Struggle for Democracy. Boulder: Lynne Rienner.

ICG (International Crisis Group) (2003). 'Sierra Leone: The State of Security and Governance. Africa Report 67. Brussels: ICG.

ICG (International Crisis Group) (2004). 'Liberia and Sierra Leone: Rebuilding Failed States’. Africa Report 87. Brussels: ICG.

Kamara, U. B. (2003). 'Mineral Rights, Ownership, Access and Exploitation'. Sierra Leone: DFID Diamond Sector Workshop. Freetown: DFID, 8-13.

Ndola-Myers, L. (2003). 'Diamond Exports, a GGDO perspective'. Sierra Leone: DFID Diamond Sector Workshop. Freetown: DFID, 62-100.

OECD (various years) Geographical Distribution of Financial Flows to Developing Countries. Paris: OECD.

PANA Press (2003a). 'Sierra Leone MP Jailed for Illegal Possession of Diamonds'. PANA Press, 24 September.

PANA Press (2003b). 'South Africa Drills Sierra Leonean Police in Diamond Probing'. PANA Press, 11 November. 
Paris, R. (2002). Human Security: Paradigm Shift or Hot Air?'. International Security, 26 (2): 87-102.

Reno, W. (1995). Corruption and State Politics in Sierra Leone. Cambridge: Cambridge University Press.

Reno, W. (1998). Warlord Politics and African States. Boulder: Lynne Rienner.

Reno, W. (2004). Sierra Leone, Countries at the Crossroads 2004: A Survey of Democratic Governance. Washington, DC: Freedom House.

Simpson, S. (2003). 'Sierra Leone’s Recovery Needs Donors and Diamonds'. West Africa, 4373: 28 April-4 May.

Smillie, I., L. Gberie, and R. Hazleton (2000). The Heart of the Matter: Sierra Leone, Diamonds and Human Security. Ottawa: Partnership Africa Canada.

UN (United Nations). Sierra Leone-UNAMSIL_Facts and Figures. Available at www.un.org/Depts/dpko/missions/unamsil/facts.html. Accessed 14 June 2005.

UNDP (2004). Human Development Report 2004. New York: Oxford University Press.

UNSC (United Nations Security Council) (2005). 'Twenty-Fifth Report of the Secretary-General on the United Nations Mission in Sierra Leone'. Document S/2005/273. New York: United Nations.

UNOCHA (UN Office for the Coordination of Humanitarian Affairs) (2003). 'Sierra Leone: President Puts Tighter Controls on Diamond Mining'. IRIN News Briefs, 21 June.

UNOCHA (UN Office for the Coordination of Humanitarian Affairs) (2004a). 'Sierra Leone: Disarmament and Rehabilitation Completed after Five Years'. IRIN News Briefs, 4 February.

UNOCHA (UN Office for the Coordination of Humanitarian Affairs) (2004b). 'Sierra Leone: Special Court Opens its Doors amid Controversies'. IRIN News Briefs, 15 March.

WFP (World Food Programme) (2005). World Hunger: Sierra Leone-Country Brief. Available at www.wfp.org/country_brief/indexcountry.asp?country=694>. Accessed 15 June 2005.

Zack-Williams, A. B. (1999). 'Sierra Leone: The Political Economy of Civil War, 1991-98’. Third World Quarterly, 20 (1), 143-62. 